\title{
THE RELATIONSHIP BETWEEN CHILD NURTURING PATTERN, FAMILY SUPPORT, AND LANGUAGE COMPETENCE IN CHILDREN AGED 5-6 YEARS WITH AUDITORY DISORDER
}

\author{
Dewi Tirtawati ${ }^{1}$, Nunuk Suryani²), Rita Benya Adriani ${ }^{1)}$ \\ ${ }^{1)}$ School of Health Polytechnics Surakarta \\ 2)Faculty of Teaching and Educational Sciences, Sebelas Maret University
}

\begin{abstract}
Background: Hearing is one of the important senses for human that functions as a communication tool and education. Lack of hearing ability in children may hinder development and lead to problem in language and speaking ability. In turn it may affect academic achievement. Hearing disorder therefore needs to be detected early. This study aimed to determine the relationship between child nurturing pattern, family support, and language competence in children aged 5-6 years with auditory disorder.

Subjects and Method: This study was analytic and observational with cross sectional design. It was carried out at "Jala Puspa" Children Observation Garden (Taman Observasi Anak "Jala Puspa”) Dr. Ramelan Navy Hospital, Surabaya, East Java. A total sample of 40 children aged 5-6 years with their parents were selected for this study by simple random sampling. The dependent variable was language competence. The independent variables were child nurturing pattern and family support. The data were collected by a set of questionnaire, and were analyzed by logistic regression.
\end{abstract}

Results: There were positive relationship between nurturing pattern ( $\mathrm{OR}=$ $10.05 ; 95 \% \mathrm{CI}=1.85$ to $54.73 ; \mathrm{p}=0.008)$, family support $(\mathrm{OR}=6.76 ; 95 \% \mathrm{CI}=$ 1.36 to $33.51 ; \mathrm{p}=0.019$ ), and language competence.

Conclusion: Nurturing pattern and family support have positive relationship with language competence.

Keywords: child nurturing pattern, family support, language competence, auditory disorder

Correspondence: Dewi Tirtawati. School of Health Polytechnics, Surakarta. Email: tirta.dewi@yahoo.co.id. 